\title{
The Contemporary Significance of the Study of Gorz’s Labor
}

\section{View*}

\author{
WANG Leifeng \\ Jingdezhen Ceramic Institute, Jiangxi, China
}

\begin{abstract}
In the post-industrial period, Gorz makes a new exposition of labor liberation: The essence of Gorz so-called labor and laborers is to eliminate alienated labor, to shorten people's labor time, to make labor a creative autonomous activity, and to show their own value in labor; all kinds of activities outside the labor are also one of the important content and value of life; leisure is not the pleasure of consumption, but the search for a rich life as an interest. Specifically, Gorz's conception of the goal of labor emancipation mainly includes the liberation of labor time, the autonomy of labor, the diversity of activities, the creativity of labor, and so on; this goal of labor liberation has produced certain significance at home and abroad.
\end{abstract}

Keywords: Gorz, labor, labor emancipation, labor view, contemporary significance

After carefully reading the study of Gorz's labor view, Gorz makes a new interpretation of the times for labor liberation, criticizing the capitalist labor problem, and puts forward a new viewpoint: The combination of labor and ecology, the combination of labor and freedom, and the combination of material labor and non-material labor formed the individual view of labor. This view of labor has certain reference significance for the realization of Chinese dream. Therefore, under the current concept of green development, we can draw on the positive significance of Gorz's labor concept: Let labor inject ecological elements, make people get happiness in labor, form sufficient employment and new perspective on non-material labor, and so on. Of course, we should take a renunciation attitude towards our views in the light of the concrete reality of contemporary China.

\section{Labor Injection of Ecological Elements}

Gorz's labor from an ecological point of view is necessary to reduce the use of economic rationality and exchange value, and to meet people's basic needs to the maximum extent, not to pursue the maximization of profits, but to endow the social ecological direction of labor; the purpose of which is to liberate both labor and workers. This shows that Gorz inherits the Marxist view of labor to a certain extent, that is, Marx thinks that labor is the creative activity of human beings, can realize the activities of self in labor, and embody the nature of human freedom. This can arouse people's re-understanding of labor, make people from the labor alienation of the production and consumption of the concept of the imprisonment of liberation, and limit unnecessary

\footnotetext{
*Acknowledgement: The stage results of the “Gorz's labor view and its contemporary enlightenment” of the Social Sciences research project of Jingdezhen Ceramic Institute, and this paper is the stage achievement of the 2018 Jiangxi Province Art Planning Project “The Study of productive protection of porcelain handcrafting in Jingdezhen” (YG2018235).

WANG Leifeng, lecturer, Jingdezhen Ceramic Institute, Jiangxi, China.
} 
labor; China's reference is undoubtedly included in the combination of labor and ecology. In today's China, combined with the "green development concept" put forward by the Ninth Plenary Meeting, we should have the consciousness of ecological protection in production or consumption, and practice the idea of combining labor with ecology. In this way, it contributes to the realization of harmony among man, nature, and society.

\section{To Get Happiness in Labor}

Gorz's combination of work and happiness provides a new picture of people's lives. How do people get the happiness of their personal lives in their labor? Gorz thought that labor becomes an autonomous and creative behavior, so that people get rid of the control of economic rationality, especially cannot let labor only become a means of earning money, in the labor as far as possible to obtain the satisfaction of personal life, which means that no longer work as a goal in life. The future socialism envisaged by Gorz is what Marx said a communist society. As Marx put it: "It will be such a union, where the free development of every human being is a condition for the free development of all” (Central Compilation \& Translation Bureau, 2009, p. 53). "In Gorz's view, more and more people are not content with regular jobs, trying to find their own way of activity or lifestyle, and they have to balance their work with the pleasures of other lives" (Gorz, 1999, p. 60). Gorz thought that they are the unsung heroes of precarious work, choosing pioneers of working hours. Therefore, the laborers should arrange the time reasonably, change the concept of "work first", seek the balance of work life, enhance the happiness of personal life, and have important significance for people's happiness and the realization of Chinese dream.

\section{Adequate Employment Is the Guarantee of the Happiness of the Whole People}

While focusing on ecological factors and the need for sustainable development in production and consumption, it is a better job security to emphasize the importance of the "social income plan" and to establish a basic social income for every citizen (Gorz, 1985) to realize that adequate employment is the guarantee of people's happiness, therefore, at present, in the process of building a modern society, there are non-metric economic organizations, we should adhere to the "harmonious labor relations are mutually beneficial and win-win, the management for labor to create employment opportunities, labor for the management to bring profits” (Wu, 2010, p. 35). Although the mode of employment is diversified; the employment channels are extensive; and the employment structure is optimized, the traditional labor jobs are reduced; there is a problem of unemployment, and in the future, workers should be encouraged to correctly treat unemployment and independent career selection, and to encourage independent entrepreneurship. We will strengthen the government's macro-control of employment and step out of a employment policy with Chinese characteristics, such as relying on the Internet to promote employment channels, so as to effectively improve people's employment opportunities and maintain social stability, on the basis of which, improve labor productivity and promote economic and social development and people's livelihood improvement in an innovative and driven manner.

\section{Viewing Immaterial Labor From a New Perspective}

According to Gorz, non-material labor cannot be treated by traditional work, this view is based on the review of today's capitalist situation, the analysis of the new changes and forms of capitalist labor, summed up its characteristics, to a certain extent, can be understood as in the post-industrial society, Gorz absorbed Marx's 
"immaterial production labor" thought. Because Gorz believes that Karl Marx has long recognized that knowledge is the main source of (maximum productivity) and wealth, measuring "the direct form of labor" had to stop, with the result that measurable wealth was created. The creation of wealth depends on less labour time and the amount of labor employed; and more and more progress is being made in relying on science and technology. Compared to general scientific labor, direct labor and its number will disappear with the way production is decided, which, of course, is an essential but secondary process. Now, the "production process" is no longer mistaken for a "labor process" (Gorz, 2010, pp. 2-3). Similarly, Gorz said that immaterial labor can produce economic value, is the driving force of social development, for capital proliferation services, can be seen, is still a new form of capital exploitation of workers, by capital into the production process, and gradually occupy a major position in the production of capitalist society, and become a real sense of capitalist production and labor.

\section{Conclusion}

The issue of "emancipation of labor” is a new research hotspot. Gorz's view of labor is based on the actual situation of the society in the Western developed countries; he always explores the emancipation of labor from the standpoint of individual existentialism, and puts forward a series of ways of labor liberation. Special attention should be paid to the application of Gorz's emancipation road to the Western developed welfare state, for China, under the current concept of shared development, learning and studying Gorz's view of labor, such as the diversity of activities and the innovation of labor, rational consumption, and the adoption of ecological technology, helps people to view labor from an ecological point of view and re-understand labor, attaching importance to the creativity of labor helps people to enjoy a happy life in their labor and realize the unity of personal value and social value.

\section{References}

Central Compilation \&Translation Bureau. (2009). Marx and Engels collection (Vol. 2). Beijing: People’s Press. Gorz, A. (1985). Paths to paradise: On the liberation from work. London and Sydney: Pluto Press. Gorz, A. (1999). Reclaiming work. Cambridge: Polity Press. Gorz, A. (2010). The immaterial knowledge, value and capital. Calcutta, India: Seagull Books. Wu, N. (2010). Gorz’s employment theory and its significance. Wuling Journal, (2), 35. 